\title{
An Assessment of Heavy Metals Contents in the Soil around a Cement Factory in Ewekoro, Nigeria Using Pollution Indices
}

\author{
Hussein K. Okoro ${ }^{1,4 *}$, Benjamin O. Orimolade ${ }^{1}, G_{\text {Ganiyu B. Adebayo }}{ }^{\text {, Biliqis A. Akande }}{ }^{2}$, \\ Bhekumusa J. Ximba ${ }^{3}$, J. Catherine Ngila $^{4}$ \\ ${ }^{1}$ Environmental-Analytical Research Group, Department of Industrial Chemistry, Faculty of Physical Sciences, \\ University of Ilorin, PMB 1515, Ilorin, Nigeria \\ ${ }^{2}$ Department of Chemistry, Faculty of Physical Sciences, University of Ilorin, P.M.B. 1515, Ilorin, Nigeria \\ ${ }^{3}$ Environmental-Analytical Research Laboratory, Department of Chemistry, Faculty of Applied Science Cape Peninsula \\ University of Technology, P.O. BOX 1906, Cape Town, 7535 Republic of South Africa \\ ${ }^{4}$ Analytical-Environmental and Membrane Nanotechnology Research Group, Department of Applied Chemistry, \\ University of Johannesburg, P.O. Box 17011, Doornfontein 2028, Johannesburg, Republic of South Africa
}

\author{
Received: 10 February 2016 \\ Accepted: 29 March 2016
}

\begin{abstract}
This study investigated the concentrations of heavy metals in soils around the WAPCO cement factory in Ewekoro in southwestern Nigeria. A total of 27 soil samples were collected from three locations (Ewekoro, Papalanto, and Itori) around the cement factory. Atomic absorption spectroscopy was used to determine the concentrations of metals. The results revealed that the mean values of the metals content in the three soil samples were in the order: $\mathrm{Fe}>\mathrm{Zn}>\mathrm{Mn}>\mathrm{Cr}>\mathrm{Cu}>\mathrm{Pb}$. The concentrations of $\mathrm{Pb}$ present in Ewekoro and Papalanto samples were 0.391 and $0.243 \mathrm{mg} / \mathrm{kg}$, respectively while $\mathrm{Pb}$ was not found in the control area (Itori). The concentrations of the heavy metals in the soil samples were found to decrease as the distances of the communities from the cement factory increased. Our study revealed that study area soils were affected by dust emissions from the cement factory as shown in the very low concentrations of heavy metal contents of the control study area, Itori.
\end{abstract}

Keywords: heavy metals, cement, pollution indices, soil, Ewekoro, Nigeria

\section{Introduction}

The presence of material or energy in water, land, and air at levels that cause harmful effects to the earth's natural balance or lowers the quality of life is generally referred to as environmental pollution [1].

*e-mail: okoroowo@yahoo.com; hkoadeola@gmail.com
Due to industrialization, several countries have attained sustainable development with some degree of environmental degradation. These activities on the environment, however tend to produce pollutants that may include gases, acids, oils, cooling water, and so on. Where there is no serious concern for the environment or measures for containing these problems, several issues (such as indiscriminate dumping of waste, illegal mining, 
oil spillage, and evolution of poisonous gases) often make untreated wastewater and pollution inevitable. These issues can be more prevalent in the least developed countries, to the extent that oftentimes industries are located without due regard to physical planning [2].

The cement industry is one of the most polluting industries listed by the Central Pollution Board, with its major pollutants being noise and dust. The pollutants are emitted at every stage of the manufacturing process, including extraction of the raw materials, crushing, production, etc. Cement dust changes the elemental concentration of soil and its physicochemical properties [3]. It is also the major source of such particulate matter as $\mathrm{SO}_{x}, \mathrm{NO}_{x}$, and $\mathrm{CO}_{2}$ emissions. The dust contains heavy metals like chromium, nickel, cobalt, lead, and mercury, which are hazardous to the environment and affect human and animal health. Cement dust may also cause carcinogenesis, decreased antioxidant capacity, acute respiratory symptoms, and acute ventilatory effects in man and animal [4].

Some researchers have investigated the impact of cement dust from the cement industry on soil properties and plant growth. Arpita and Mitko reported that top soils near a cement factory in Rockfort, Kingston, Jamaica are enriched with $\mathrm{Pb}, \mathrm{Zn}, \mathrm{Cr}, \mathrm{Cd}, \mathrm{V}$, and $\mathrm{Hg}$, which are released into the air from cement kilns [5]. Al-Khashman and Shawabkeh also reported that the area close to a cement factory in southern Jordan has the highest $\mathrm{Pb}$, $\mathrm{Zn}$, and Cd levels on topsoils 0-10 $\mathrm{cm}$ deep [6]. A similar study by Zerrouqi et al. observed that calcium oxide and sulfur oxide are the principal components of pollution in soil surrounding a cement factory in Morocco [3]. The results of elementary chemical analysis expressed in weight percent of oxides, conducted by Young-Chull and Jae-Min, revealed that the raw material dust of the first grinding process primarily consisted of $\mathrm{CaO}(41.77 \%)$, $\mathrm{SiO}_{2}$ (11.72\%), $\mathrm{Al}_{2} \mathrm{O}_{3}(3.45 \%)$, and $\mathrm{Fe}_{2} \mathrm{O}_{3}$ (1.47\%) [7]. $\mathrm{Ca} / \mathrm{Si}$ ratios computed by Asubiojo et al. found that soil contamination, due to cement, decreases sharply with distance from the factories and with increasing depth from the surface [8].

A study by Semhi et al. on dust emitted from cement industries in Oman showed high concentrations of heavy metals in soils within a radius of $0.5-2 \mathrm{~km}$ around a cement factory [9]. A study on the effect of cement dust after 25 years of cement production on soil physicochemical properties by Asadu and Agada has revealed that exchangeable $\mathrm{Ca}, \mathrm{Na}, \mathrm{H}$, and $\mathrm{Mg}$, as well as soil organic matter, were significantly higher in the affected soils than in the non-affected soils [10]. Studies by Gbadebo

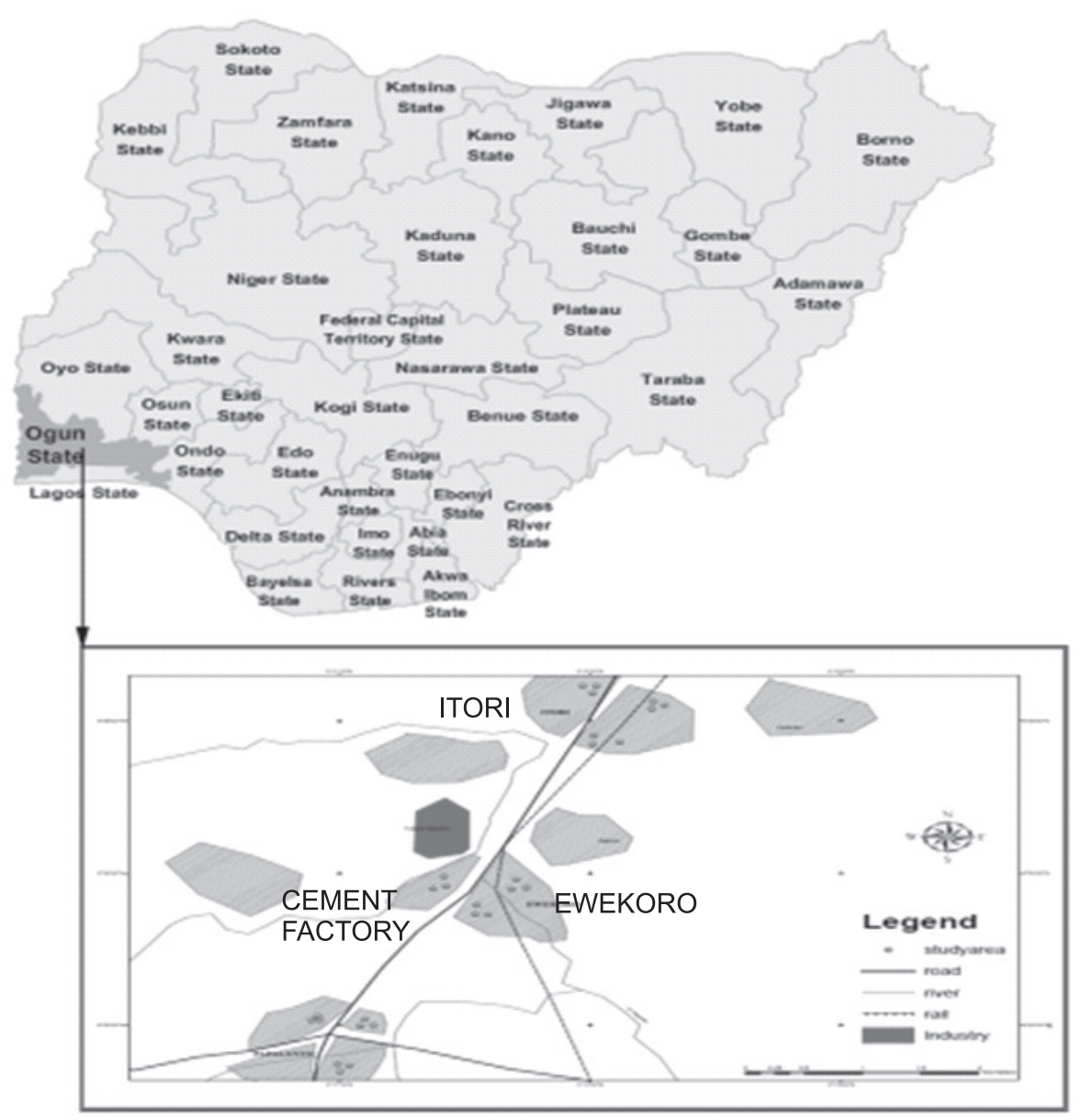

Fig. 1. The sampling locations. 
and Bankoleon on the heavy metal pollution of the air and dusts surrounding the West African Portland Cement Company (WAPCO), in southwest Nigeria [11]. Similarly,Ogunkunle and Fatoba reported that heavy metals are present in the soil around a cement factory in Nigeria $\mathrm{Pb}, \mathrm{Cu}, \mathrm{Cd}$, and $\mathrm{Cr}$ with mean concentrations of $666.1 \mathrm{mg} / \mathrm{kg}, 613.4 \mathrm{mg} / \mathrm{kg}, 547.9 \mathrm{mg} / \mathrm{kg}$, and $188.5 \mathrm{mg} /$ $\mathrm{kg}$, respectively which were above international limits [12]. Ewekoro is one of the villages along the Sango-IfoAbeokuta expressway of Ogun State of Nigeria. Ewekoro borders Papalanto in the west, Abeokuta in the east, and numerous villages along the northern and southern axis. The climate is not different from the towns and villages mentioned earlier.

However, the establishment of West African Portland Cement Company (WAPCO) now referred to as LafargeCement WAPCO changed the economic sphere of this once sleepy and serene town [13]. The activities of this industry in Ewekoro constitute a source of environmental pollution, thus subjecting the inhabitants to hardship from dust-laden air, cracking of walls of structures, and soil and water polluted by dust. Previous studies have shown the presence of heavy metals in the particulate matters released from cement industries, which are hazardous to living organisms. The fine particulates of dust can be easily inhaled, and over time cause respiratory problems in people living near and working in the factory. It is therefore necessary to determine the concentrations of the heavy metals in soils around the cement industry, since no such report has been made in recent times.

Our study was therefore aimed at assessing the heavy metal concentrations in soils around WAPCO Ewekoro in order to assess the level of pollution that may be done to the communities where the factory is located.

\section{Materials and Methods}

\section{Description of Study Area}

The study was carried out in the towns of Ewekoro, Papalanto, and Itori - all part of the Ewekoro Local

Table 1. Sampling coordinates.

\begin{tabular}{|c|c|c|}
\hline Town & Sampling Areas & Coordinates \\
\hline \multirow{4}{*}{ Ewekoro } & 1 & $6^{\circ} 54^{\prime} 36^{\prime \prime} \mathrm{N}, 3^{\circ} 12^{\prime} 45^{\prime \prime} \mathrm{E}$ \\
\cline { 2 - 3 } & 2 & $6^{\circ} 54^{\prime} 43^{\prime \prime} \mathrm{N}, 3^{\circ} 12^{\prime} 39^{\prime \prime} \mathrm{E}$ \\
\cline { 2 - 3 } & 3 & $6^{\circ} 54^{\prime} 40^{\prime \prime} \mathrm{N}, 3^{\circ} 12^{\prime} 44^{\prime \prime} \mathrm{E}$ \\
\hline \multirow{4}{*}{ Papalanto } & 4 & $6^{\circ} 53^{\prime} 11^{\prime \prime} \mathrm{N}, 3^{\circ} 11^{\prime} 44^{\prime \prime} \mathrm{E}$ \\
\cline { 2 - 3 } & 5 & $6^{\circ} 53^{\prime} 04^{\prime \prime} \mathrm{N}, 3^{\circ} 11^{\prime} 40^{\prime \prime} \mathrm{E}$ \\
\hline \multirow{4}{*}{ Itori } & 6 & $6^{\circ} 52^{\prime} 60^{\prime \prime} \mathrm{N}, 3^{\circ} 11^{\prime} 31^{\prime \prime} \mathrm{E}$ \\
\cline { 2 - 3 } & 7 & $6^{\circ} 56^{\prime} 23^{\prime \prime} \mathrm{N}, 3^{\circ} 13^{\prime} 14^{\prime \prime} \mathrm{E}$ \\
\cline { 2 - 3 } & 9 & $6^{\circ} 56^{\prime} 15^{\prime \prime} \mathrm{N}, 3^{\circ} 13^{\prime} 07^{\prime \prime} \mathrm{E}$ \\
\hline
\end{tabular}

Government Area of Ogun State in southwestern Nigeria. Ewekoro cement factory is located $5 \mathrm{~km}$ north of Ewekoro and is within the tropical rainforest belt of Ogun. The topography of Ewekoro is classified as southern upland [14]. It has an area of $594 \mathrm{~km}^{2}$ and a population of 55,156 (2006). Papalanto is a sugarcane community south of Ewekoro and Itori is a farming community north of Ewekoro.

A map showing the location of the sampling area in Ewekoro Local Government Area is shown in Fig. 1, while the location sites and coordinates are presented in Table 1.

\section{Sample Collection}

Composite top soil samples $(0-15 \mathrm{~cm})$ were taken randomly in triplicates from three different locations in the three towns for a total of 27 soil samples. The soil samples were collected in a ziplock bag and brought to the laboratory for analysis. Soil samples were air-dried before being crushed gently and sieved through a $2 \mathrm{~mm}$ sieve and stored for analysis [15].

\section{Sample Preparation}

Before being analyzed for the heavy metals, the samples were digested using aqua regia (hydrochloric acid: nitric acid, in a 1:3 volume ratio). One gram of the sample was weighed into a beaker. $10 \mathrm{ml}$ hydrochloric acid and $30 \mathrm{ml}$ nitric acid were added and covered so as to allow for any reaction to subside. The mixture was then placed on a hot plate and heated at $100^{\circ} \mathrm{C}$ for about 20 minutes. After digestion the solution was allowed to cool and then filtered. The filtrate was then made up to the $50 \mathrm{ml}$ (or more) volume and transferred to plastic bottles. Heavy metals in the samples were determined with BUCK SCIENTIFIC 210/211VGPAtomic Absorption Spectrophotometer [16].

\section{Soil Pollution Indices}

The geo-accumulation index (I-geo) and pollution load index (PLI) were employed to assess the pollution of metals in the soil samples.

\section{Geo-Accumulation Index (I-geo)}

The geo-accumulation index was determined by the following equation as described by Boszke et al. [17].

$$
\mathrm{I}-\mathrm{geo}=\log 2(\mathrm{Cn} / 1.5 \mathrm{Bn})
$$

$\mathrm{Cn}$ is the measured concentration of heavy metal in the soil samples. $\mathrm{Bn}$ is the geochemical background value in average shale of element $\mathrm{n}$ [18]. Factor 1.5 is used for the possible variations of the background data due to lithological variations.

I-geo was classified into seven grades: I-geo $\leq 0$ (grade 0 ), unpolluted; $0<$ I-geo $\leq 1$ (grade 1), slightly polluted; $1<$ I-geo $\leq 2$ (grade 2 ), moderately polluted; $2<$ I-geo $\leq 3$ 
(grade 3 ), moderately severely polluted; $3<$ I-geo $\leq 4$ (grade 4), severely polluted; $4<$ I-geo $\leq 5$ (grade 5), severely extremely polluted; I-geo $>5$ (grade 6 ), extremely polluted [19-20].

\section{The Pollution Load Index}

The pollution load index (PLI) is obtained as concentration factors (CFs). This $\mathrm{CF}$ is the quotient obtained by dividing the concentration of each metal. The PLI of the place is calculated by obtaining the n-root from the $n-C F s$ that were obtained for all the metals obtained from each place [20].

Generally, pollution load index (PLI) as developed by Tomlinson et al. [19] is as follows:

$$
\begin{aligned}
& \mathrm{CF}=\mathrm{C}_{\text {metal }} / \mathrm{C}_{\text {background value }} \\
& P L I=n \sqrt{ }(C F 1 \times C F 2 \times C F 3 \times \ldots x C F n)
\end{aligned}
$$

$\mathrm{CF}$ is contamination factor, $\mathrm{n}$ is the number of metals, $\mathrm{C}_{\text {metal }}$ is the metal concentration in polluted soil samples, and $\mathrm{C}_{\text {Background value }}$ is the background value of that metal. The background values used were 850, 47, 50, 90, 100 and $20 \mathrm{mg} / \mathrm{Kg}$ for $\mathrm{Mn}, \mathrm{Fe}, \mathrm{Cu}, \mathrm{Zn}, \mathrm{Cr}$ and $\mathrm{Pb}$ respectively. A PLI value greater than 1 is polluted, whereas a PLI value less than 1 indicates no pollution [22].

\section{Results and Discussion}

The results of the concentrations of heavy metals present in the three locations studied are presented Table 2 in terms of simple statistical parameters which are mean and standard error. The mean values of the metal concentrations in the soil samples (i.e., from the three communities) are found to be higher than the average concentrations and the normal ranges in soils, which is in line with previous reports $[19,23]$. The mean values of the metals content in the three communities' soil samples could be arranged in the following descending order: $\mathrm{Fe}>\mathrm{Zn}>\mathrm{Mn}>\mathrm{Cr}>\mathrm{Cu}>\mathrm{Pb}$ (Table 2; obviously, the levels of $\mathrm{Mn}, \mathrm{Zn}$, and $\mathrm{Fe}$ were higher than those of $\mathrm{Cr}, \mathrm{Cu}$, and $\mathrm{Pb}$ ).

\section{Distributions of Heavy Metals Across the Three Communities}

The distributions of the heavy metals across the three communities are shown in Fig. 2. All the heavy metals studied were found in significant amounts at different levels and at all locations. However, the metals were concentrated more at Ewekoro than at the two other communities. Papalanto's metal content was quite high but not as high as Ewekoro's, and Itori's concentration was reasonably low. It is worth mentioning that most of the heavy metal-contaminated soil samples were found in Ewekori, where the cement factory is located. This finding is in agreement with the results reported by Al-Omran et al. [24].

Papalanto has the highest occurrence of Manganese with an average percent of $45.7 \%$ and a mean metal concentration of $17.35 \mathrm{mg} / \mathrm{kg}$. The average concentration value was found to be above the WHO limits, suggesting its toxicity in the soil sample. Related research work carried out on this metal revealed that the metal was generally very high above health standards of federal and world organizations [25].

Ewekoro has the highest iron concentration (9.69 $\mathrm{mg} / \mathrm{kg}$ ), while Itori has a minimum value of $5.37 \mathrm{mg} / \mathrm{kg}$. The iron concentration was found to be above 2006 WHO limits, which may be due to the deposition of the cement dust on the soil. It also averages $44.5 \%$. The effect of cement dust pollution on the available Fe in the soil was statistically significant [26]. The order of metal abundance in decreasing order was Ewekoro $>$ Itori $>$ Papalanto.

The order of abundance of copper in decreasing order also followed a similar trend. Copper metal concentration was found to be highest at Ewekoro with a value of $1.46 \mathrm{mg} / \mathrm{kg}$, and least at Itori with an average of

Table 2. Concentration of heavy metals in different locations ( $\mathrm{mg} / \mathrm{kg})$.

\begin{tabular}{|c|c|c|c|c|c|c|c|}
\hline Sample & & $\mathrm{Mn}(\mathrm{mg} / \mathrm{kg})$ & $\mathrm{Fe}(\mathrm{mg} / \mathrm{kg})$ & $\mathrm{Cu}(\mathrm{mg} / \mathrm{kg})$ & $\mathrm{Zn}(\mathrm{mg} / \mathrm{kg})$ & $\mathrm{Cr}(\mathrm{mg} / \mathrm{kg})$ & $\mathrm{Pb}(\mathrm{mg} / \mathrm{kg})$ \\
\hline \multirow{4}{*}{ Location } & & Mean $\pm \mathrm{SE}$ & $\mathrm{Mean} \pm \mathrm{SE}$ & $\mathrm{Mean} \pm \mathrm{SE}$ & $\mathrm{Mean} \pm \mathrm{SE}$ & $\mathrm{Mean} \pm \mathrm{SE}$ & $\mathrm{Mean} \pm \mathrm{SE}$ \\
\hline \multirow{5}{*}{ Ewekoro } & $\mathrm{A}$ & $2.90 \pm 0.11$ & $184.71 \pm 9.21$ & $0.38 \pm 0.02$ & $2.57 \pm 1.04$ & $0.46 \pm 0.01$ & $0.23 \pm 0.00$ \\
\cline { 2 - 9 } & $\mathrm{B}$ & $4.23 \pm 0.33$ & $373.64 \pm 23.05$ & $0.54 \pm 0.01$ & $5.98 \pm 1.68$ & $0.59 \pm 0.02$ & $0.29 \pm 0.03$ \\
\cline { 2 - 9 } & $\mathrm{C}$ & $4.62 \pm 0.43$ & $412.12 \pm 11.65$ & $0.54 \pm 0.03$ & $4.85 \pm 0.66$ & $0.64 \pm 0.03$ & $0.39 \pm 0.03$ \\
\hline \multirow{5}{*}{ Papalanto } & $\mathrm{A}$ & $2.43 \pm 0.21$ & $97.46 \pm 11.75$ & $0.32 \pm 0.04$ & $3.26 \pm 0.05$ & $0.38 \pm 0.03$ & $0.11 \pm 0.00$ \\
\cline { 2 - 9 } & $\mathrm{B}$ & $6.36 \pm 0.47$ & $370.40 \pm 17.54$ & $0.53 \pm 0.14$ & $4.27 \pm 0.63$ & $0.64 \pm 0.06$ & $0.16 \pm 0.08$ \\
\cline { 2 - 9 } & $\mathrm{C}$ & $8.56 \pm 0.28$ & $403.66 \pm 18.82$ & $0.48 \pm 0.05$ & $3.24 \pm 0.07$ & $0.66 \pm 0.12$ & $0.24 \pm 0.08$ \\
\hline & $\mathrm{A}$ & $2.47 \pm 0.06$ & $440.63 \pm 26.72$ & $0.19 \pm 0.09$ & $1.63 \pm 0.63$ & $0.52 \pm 0.05$ & $0.18 \pm 0.00$ \\
\cline { 2 - 9 } & $\mathrm{B}$ & $3.90 \pm 0.32$ & $140.00 \pm 19.64$ & $0.39 \pm 0.03$ & $3.51 \pm 0.28$ & $0.33 \pm 0.00$ & $0.00 \pm 0.00$ \\
\cline { 2 - 9 } & $\mathrm{C}$ & $2.50 \pm 0.16$ & $91.41 \pm 5.31$ & $0.31 \pm 0.03$ & $3.23 \pm 0.15$ & $0.33 \pm 0.02$ & $0.00 \pm 0.00$ \\
\hline
\end{tabular}



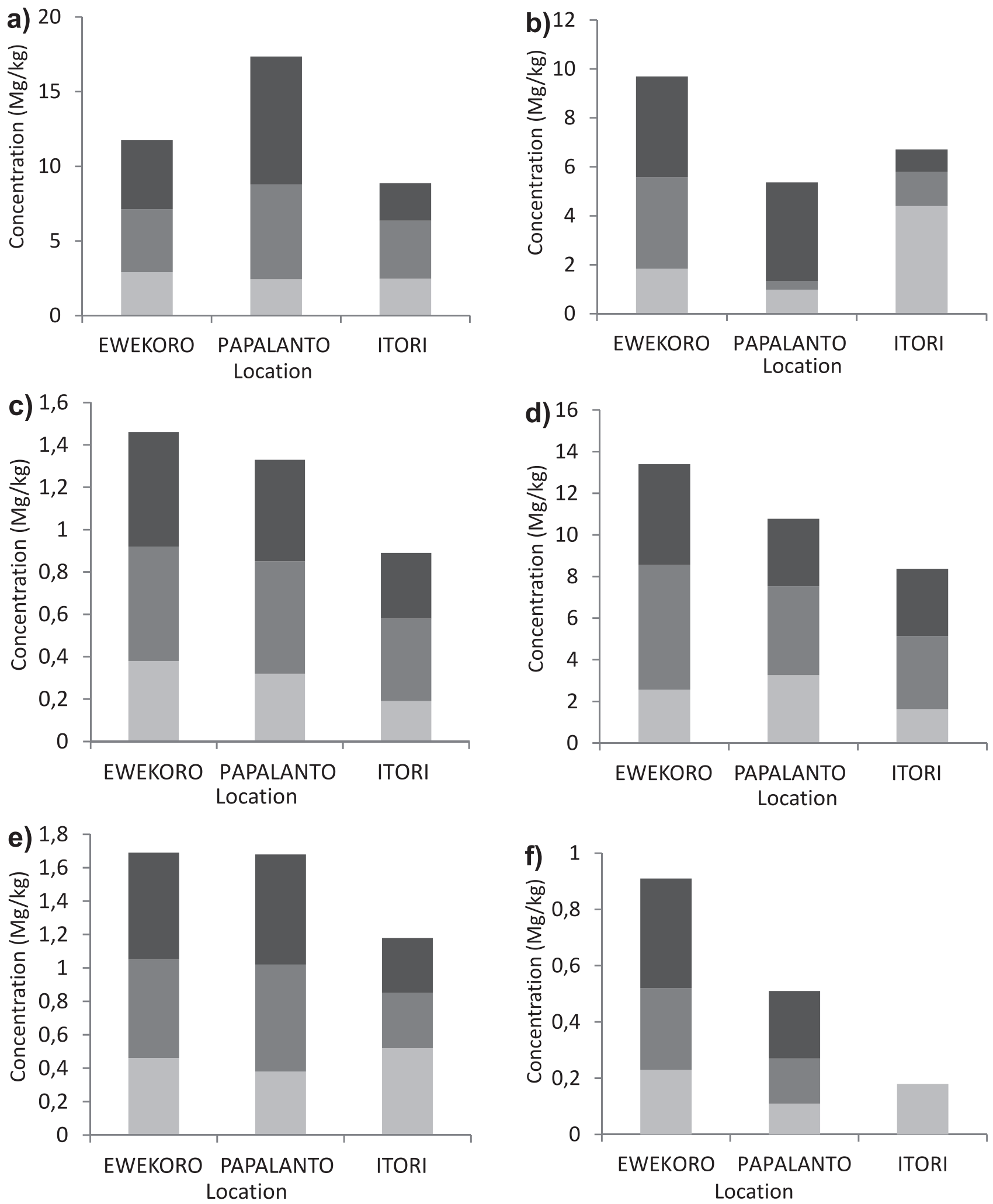

Fig. 2. Distribution of: a) manganese, b) iron $\left(10^{-2}\right)$, c) copper, d) zinc, e) chromium, f) lead.

$0.89 \mathrm{mg} / \mathrm{kg}$. The high values have been attributed to cement dust emissions from the cement factory [25].

Zinc has the highest value of $13.4 \mathrm{mg} / \mathrm{kg}$ at Ewekoro, followed closely by Papalanto with $10.77 \mathrm{mg} / \mathrm{kg}$. At close distance (Ewekoro) from the cement factory, the soil exhibits higher $\mathrm{Zn}$ values than further away from the factory, which can be attributed to recent deposition of the polluting dust. The observation that $\mathrm{Zn}$ is known to have higher mobility in soil profiles has been reported by Luke et al. [27].

The results of chromium showed a close range of values of $1.69 \mathrm{mg} / \mathrm{kg}$ and $1.68 \mathrm{mg} / \mathrm{kg}$ at Ewekoro and Papalanto, 
Table 3. Pearson's correlation coefficient between metal levels in soil samples.

\begin{tabular}{|c|c|c|c|c|c|c|}
\hline & $\mathrm{Mn}$ & $\mathrm{Fe}$ & $\mathrm{Cu}$ & $\mathrm{Zn}$ & $\mathrm{Cr}$ & $\mathrm{Pb}$ \\
\hline $\mathrm{Mn}$ & 1.000 & $0.528^{* *}$ & $0.535^{* *}$ & 0.24 & $0.637^{* *}$ & $0.462^{*}$ \\
\hline $\mathrm{Fe}$ & & 1.000 & 0.290 & 0.183 & $0.794^{* *}$ & $0.608^{* *}$ \\
\hline $\mathrm{Cu}$ & & & 1.000 & $0.674^{* *}$ & $0.497^{* *}$ & $0.585^{* *}$ \\
\hline $\mathrm{Zn}$ & & & & 1.000 & 0.269 & $0.412^{*}$ \\
\hline $\mathrm{Cr}$ & & & & & 1.000 & $0.550^{* *}$ \\
\hline $\mathrm{Pb}$ & & & & & & 1.000 \\
\hline
\end{tabular}

with averages of $37.1 \%$ and $36.9 \%$, respectively. Itori has an average value of $1.18 \mathrm{mg} / \mathrm{kg}$. In the cement factory (as reported by Banat et al.), the linings for the rotaries contain $\mathrm{Cr}$, which could be liberated by wear and tear of the machine due to friction [28]. Hence the source of $\mathrm{Cr}$ in the soil samples may be attributed to this process. Thus, decreasing trends were observed as Ewekoro $>$ Papalanto $>$ Itori.

The recorded values for lead ranged from a minimum of $0.18 \mathrm{mg} / \mathrm{kg}$ at Itori to $0.91 \mathrm{mg} / \mathrm{kg}$ at Ewekoro, which has an average of $56.9 \%$. The high concentrations of lead at Ewekoro could be attributed to the cement industry in which the process and production of cement requires a substantial amount of energy supplied by burning fossil fuel and traffic activity in the plant. Ewekoro > Papalanto $>$ Itori.

\section{Pearson Correlation Coefficient}

The Pearson correlation coefficient is a measure of the strength of the linear relationship between two variables. Pearson's correlation coefficient between the metals level in the soil samples is shown in Table 3.

From Table 3, the correlation is significant at the 0.05 levels (two-tailed) and the values with $*$ and $* *$ mean the particular bi-variate metal is significant, i.e., there is a relationship between them and otherwise for those without.

Data in Table 3 indicates that most of the correlations between the studying metals are significant. The correlations between $\mathrm{Cr}$ and other metals are the strongest. The strongest correlation was found between $\mathrm{Cr}$ and $\mathrm{Fe}$ (0.794), followed by $\mathrm{Zn}$ and $\mathrm{Cu}(0.674)$, and $\mathrm{Cr}$ and $\mathrm{Mn}$ (0.637). This finding was supported totally by an earlier study that reported the correlation between $\mathrm{Cr}$ and other metals as being strong [24].

\section{Pearson's Correlation Using P-Values}

According to Table 4, p-values less than 5\% (0.05) are said to be significant and a relationship exists between the elements.

The data obtained in Table 4 were in agreement with the results of Arpita and Mitko, which revealed that $\mathrm{Cr}$ shows good positive correlation with $\mathrm{Zn}$, confirming their
Table 4. P-values of correlation coefficients between the metals.

\begin{tabular}{|c|c|c|c|c|c|c|}
\hline & $\mathrm{Mn}$ & $\mathrm{Fe}$ & $\mathrm{Cu}$ & $\mathrm{Zn}$ & $\mathrm{Cr}$ & $\mathrm{Pb}$ \\
\hline $\mathrm{Mn}$ & & & & & & \\
\hline $\mathrm{Fe}$ & 0.005 & & & & & \\
\hline $\mathrm{Cu}$ & 0.004 & $0.143^{*}$ & & & & \\
\hline $\mathrm{Zn}$ & $0.226^{*}$ & $0.362^{*}$ & 0.000 & & & \\
\hline $\mathrm{Cr}$ & 0.000 & 0.000 & 0.008 & $0.174^{*}$ & & \\
\hline $\mathrm{Pb}$ & 0.015 & 0.001 & 0.001 & 0.033 & 0.003 & \\
\hline
\end{tabular}

common source, and they further suggested that these metals could be accounted for in their similar source: coal. Coal combustion releases these metals, which can get incorporated into the dust along with the cement particulates and then get deposited on the soil of the surrounding areas [7].

\section{Pollution Indices}

Table 5 shows the contamination factors of the metals in the soil samples, while Tables 6 and 7 present the pollution load index and geo-accumulation index for soil samples.

The results of contamination factor (CF) obtained for the three soil samples (Table 5) were used to calculate the Pollution Load Index for each soil sample (Table 6). From the results, it was observed that the PLI values for the three locations were not high but Papalanto and Ewekoro have higher PLI values than that of the control point, Itori which revealed that Papalanto and Ewekoro soils are relatively more polluted than Itori soil due to the activities of the cement factories.

Similarly, the geo-accumulation indices for the quantification of heavy metal accumulation in the study areas (Table) revealed the extent of pollution relating a specific metal. The I-geo grades for the soil samples vary from metal to metal and site to site (across metals and

Table 5. Contamination factors for the soil samples.

\begin{tabular}{|c|c|c|c|}
\hline & Ewekoro (CF) & Papalanto (CF) & Itori (CF) \\
\hline $\mathrm{Mn}$ & 0.005 & 0.007 & 0.003 \\
\hline $\mathrm{Fe}$ & 6.883 & 6.181 & 4.769 \\
\hline $\mathrm{Cu}$ & 0.010 & 0.009 & 0.005 \\
\hline $\mathrm{Zn}$ & 0.050 & 0.040 & 0.031 \\
\hline $\mathrm{Cr}$ & 0.006 & 0.006 & 0.004 \\
\hline $\mathrm{Pb}$ & 0.015 & 0.009 & 0.003 \\
\hline
\end{tabular}

Table 6. Pollution load index for the locations.

\begin{tabular}{|c|c|c|c|}
\hline Location & Ewekoro & Paplanto & Itori \\
\hline PLI & 0.034 & 0.031 & 0.017 \\
\hline
\end{tabular}


Table 7. Geo-accumulation index for the soil samples.

\begin{tabular}{|c|c|c|c|c|c|c|}
\hline & Ewekoro & & Papalanto & & Itori & \\
\hline & Conc $(\mathrm{mg} / \mathrm{kg})$ & I-geo & Conc $(\mathrm{mg} / \mathrm{kg})$ & I-geo & Conc $(\mathrm{mg} / \mathrm{kg})$ & I-geo \\
\hline $\mathrm{Mn}$ & 3.92 & -2.18 & 5.78 & -2.03 & 2.96 & -2.39 \\
\hline $\mathrm{Fe}$ & 323.49 & 0.96 & 290.51 & 0.92 & 224.01 & 0.80 \\
\hline $\mathrm{Cu}$ & 0.49 & -1.88 & 0.44 & -1.92 & 0.29 & -2.18 \\
\hline $\mathrm{Zn}$ & 4.47 & -1.18 & 3.59 & -1.27 & 2.79 & -1.38 \\
\hline $\mathrm{Cr}$ & 0.56 & -2.09 & 0.56 & -2.09 & 0.39 & -2.27 \\
\hline $\mathrm{Pb}$ & 0.30 & -1.69 & 0.17 & -1.92 & 0.06 & -2.39 \\
\hline
\end{tabular}

sites). Manganese, Copper, Zinc, Chromium and Lead remain in grade 0 (unpolluted) in all study area suggesting that the study area soils are in background value with respect to these metals. The I-geo value of Iron attains grade 1 in all the soil samples which indicates that the soils were slightly polluted by Iron. This could be attributed to the activities of the cement factory.

\section{Conclusion}

It has been established from the results obtained that soils in Ewekoro have been polluted to a large extent by the major elemental components and heavy metals. Due to the southward flow of the wind, Papalanto has corresponding high concentrations owing to the movement of the cement dust. The mean values of the metal concentration in the soil samples from the three communities were found to be higher than the average concentrations and the normal ranges in soils. Thus, it could be concluded that the soils of the study areas were affected by dust emissions from the cement factory as shown in the very low concentrations of heavy metal contents of the control study area, Itori. It has very low concentration ranges as compared to Ewekoro and Papalanto soil samples. Although there have been substantial efforts on the part of the management of the factory to reduce their noxious impact, more still needs to be done - especially in the area of environmental monitoring, so that, for example, the vibration and other emissions enumerated earlier could be brought under control.

\section{Acknowledgements}

The authors acknowledged the Department of Industrial Chemistry of Ilorin, University of Ilorin, Nigeria for making available the laboratory equipment used for this study. Our appreciation also goes to the Technologists of the Department for their technical support in the course of this research work. Our thanks go to Dr. Issa O. Sanusi, the acting H.O.D., Department of Linguistics, Nigerian Languages, University of Ilorin, Ilorin for the editorial assistance. Authors wish to thank the University of Johannesburg for making library database available during the revision of this manuscript.

\section{References}

1. EKUNDAYO J.A. Environmental consequences of the pollution of the Lagos lagoons. Bulletin of The Science Association of Nigeria. 3, 298, 1997.

2. COOPER F.K., DAVEY N.T., DUNWELL N.M. Environment and development. International Development Abstracts. Norwich, Elsevier. 170, 2006.

3. ZERROUQI Z., SBAA M., OUJIDI M., ELKHARMOUZ M., BENGEMRA S. ANDZERROUQI A. Assessment of cement's dust impact on the soil using principal component analysis and GIS. International Journal on Environmental Science Technology. 5 (1), 125, 2008.

4. BABY S., SINGH N.A., SHRIVASTAVA P., NATH S.R., KUMAR S.S., SINGH D. AND VIVEK K. Impact of dust emission on plant vegetation of vicinity of cement plant. Environmental Engineering Management Journal. 7 (1), 31, 2008

5. ARPITA M., MITKO V. Heavy metals in soils around the cement factory in Rockfort, Kingston, Jamaica. International Journal of Geosciences. 2, 48, 2011.

6. AL-KHASHMAN O.A., SHAWABKEH R.A. Metals distribution in soil around the cement factory in Southern Jordan. Environmental pollution. 140, 387, 2006.

7. YOUNG-CHULL A., JAE-MIN C. Physical, chemical \& electrical analysis of dust generated from cement plants for dust removal with an electrostatic precipitator. Korean Journal on Chemical Engineering. 21 (1), 182, 2004.

8. ASUBIOJO O.I., AINA P.O., OLUWOLE A O., ARSHED W., AKANLE O.A., SPYROU N. Effects of cement production on the elemental composition of soils in the neighbourhood of 2 cement factories. Water, air \& soil pollution, Kluwer Academic Publishers. 5758: 819, 1991.

9. SEMHI K., KHIRBASH S.A., ABDALLA O., KHAN T., DUPLEY J., CHAUDHURI S., SAIDI S.A. Dry Atmospheric contribution to the plant-soil system around a cement factory: Spatial variations and sources-A case study from Oman. Water, Air \& Soil pollution. 205, 343, 2010.

10. ASADU C.L., AGADA C. The impact of cement kiln dust on soil physico-chemical properties at Gboko, East central Nigeria. Nigerian journal on soil and environmental resource. 8, 1595, 2008.

11. GBADEBO A.M., BANKOLE O.D. Analysis of potentially toxic heavy metals in airborne cement dust around Sagamu, Southwestern Nigeria. Applied Sciences, 7, 35, 2007. 
12. OGUNKUNLE C.O., FATOBA P.O. Pollution loads and ecological risk assessment of soil heavy metals around a mega cement factory in Southwestern Nigeria. Polish Journalof Environmental Studies, 22 (2), 487, 2013.

13. ARIBIGBOLA A., FATUSIN A.F., FAGBOHUNKA A. Assessment of health \& environmental challenges of cement factory on Ewekoro community residents, Ogun state, Nigeria. American Journal of Human Ecology. 1 (2), 51, 2012.

14. GBADEBO A.M., AMOS A.J. Assessment of Radionuclide pollutants in bedrocks and soil, Ewekoro cement factory, Southwest Nigeria. Asian journal of applied sciences. 2, $1-10,2010$.

15. WUFEM B.M., IBRAHIM A.A, MAINA A.Q., HUMPHREY M., NANGBES J.G., JOHN B.N. Speciation of some heavy metals in soils around a cement factory in Gombe state, Nigeria. The International Journal Of Engineering And Science. 2, 110, 2013.

16. ESTIFANOS S., AYNALEM D. Assessing the effect of cement dust emission on the physicochemical nature of soil around Messebo area, Tigray, North Ethiopia. International journal on economic \& environmental geology. 3 (2), 12, 2012.

17. BOSZKE L., SOBCZYNSKI T., KOWALSKI A. Distribution of Mercury and Other Heavy Metals in Bottom Sediments of the Middle Odra river (Germany/Poland). Polish Journal of Environmental Studies, 13 (5), 495, 2004.

18. TUREKIAN K.K., WEDEPOHL K.H. Distribution of the elements in some major units of the earth's crust. American Geology Soc. Bulletin, 72, 175, 1961.

19. GALKUS A., JOKSAS K., STAKENIENE R., LAGUNAVICIENE L. Heavy metal contamination of harbour bottom sediments, Pol. J. Environ. Stud. 21 (6), $1585,2012$.

20. SOARES H.M., BOAVENTURA R.A.R., ESTEVES DA SILVA J. Sediments as Monitors ofHeavy Metal
Contamination in the AveRiver Basin (Portugal): Multivariate Analysis of Data. Environmental Pollution, 105, 311, 1991.

21. TOMLINSON D.L., WILSON J.G., HARRIS C.R., JEFFNEY D.W. Problems in the assessment of heavy metal levels in estuaries and the formation of a pollution index. Helgol.Wiss.Meeresunters, 33, 566, 1980.

22. HARIKUMAR P.S., NASIR U.P, MUJEEBU RAHMA M.P. Distribution of heavy metals in the core sediments of a tropical wetland system. International Journal Environmental Science Technology, 6 (2), 225, 2009.

23. LINDSAY W. Chemical Equilibrium in Soils. $1^{\text {st }}$ Edition. A Wiley Inter. Sci. Pub. John Wiley and Sons, New York, 1979.

24. AL-OMRAN A.M., EL-MAGHRABY S.E., MAHMOUD E.A., EL-ETER A.M., AL-QAHTANI S.M. Impact of cement dust on some soil properties around the cement factory in Al-Hasa Oasis, Saudi Arabia. American-Eurasian J. Agric. \& Environ. Sci. 11 (6), 840, 2011.

25. MAINA H.M., EGILA J.N, NKAFAMIYA I.I., SHAGAL M.H. Impact of cement dust deposition on the elemental composition of soils in the vicinity of Ashaka cement factory, Nigeria. International research journal of agricultural science and soil science. 3 (2), 66, 2013.

26. KHAMPARIA A., CHATTERGEE S.K, SHARMA G.D. Assessment on effect of cement dust pollution on soil health. Journal of environmental research and development. 7 (1A), 368, 2012.

27. LUKE B., EDUARDO M.J, RAFAEL C., NICHOLAS L., NICHOLAS D. Mobility of Arsenic, Cadmium and Zinc in a multi-element contaminated soil profile assessed by in-situ soil pore water sampling, column leaching and sequential extraction. Environmental pollution. 158, 155, 2010.

28. BANAT K.M., HOWARI F.M., AL-HAMAD A.A. Heavy metals in urban soils of central Jordan: Should we worry about their environmental risks. Environmental research. 97, $258,2005$. 